\title{
Effects of Microstructural Transformation in TBCs Consisting of NiCrAlY Metallic Bond Coat and YSZ Ceramic Top Coat after Oxidation at $900^{\circ} \mathrm{C}$
}

\begin{abstract}
A.S. PARlakYigit ${ }^{a}$ AND A.C. KaraOglanli ${ }^{b, *}$
${ }^{a}$ Istanbul Technical University, Department of Mechanical Engineering, 34469, Istanbul, Turkey

and Istanbul Medeniyet University, Department of Mechanical Engineering, 34720, Istanbul, Turkey

${ }^{b}$ Bartin University, Department of Metallurgical and Materials Engineering, 74100, Bartin, Turkey

Thermal barrier coatings are applied to aeronautical and industrial gas turbine components to protect from detrimental effects of hot gases. Thermal barrier coating systems are generally composed of a substrate material, an oxidation resistant metallic bond coat, and a thermal protective ceramic-based topcoat. Additionally, thermally grown oxide layer is formed at ceramic/bond coat interface as a result of exposure of bond coat to high temperature. Oxidation mechanism is one of the major failure mechanisms of thermal barrier coatings. Thermally grown oxide layer plays significant role as a oxygen barrier, but rapid thickening of thermally grown oxide leads to spallation failure of thermal barrier coatings. In this study, thermally grown oxide growth behavior was investigated at isothermal oxidation condition to evaluate durability of the thermal barrier coating system. The thermal barrier coating system consists of yttria stabilized zirconia (YSZ) topcoat and NiCrAlY bond coat deposited on Inconel 718 superalloy with atmospheric plasma spray technique. After coating process, specimens were exposed to $900{ }^{\circ} \mathrm{C}$ air atmosphere for different periods up to $50 \mathrm{~h}$. Ceramic/bond coat interface and thermally grown oxide layer were examined using scanning electron microscopy analysis. Besides, porosity contents and microhardness measurements were carried out to determine strength of coating. The results showed that thickness of thermally grown oxide layer increased and porosity rates of ceramic layer decreased with the effect of oxidation. Accordingly, the ceramic layer hardness increased due to high temperature effect.
\end{abstract}

DOI: 10.12693/APhysPolA.125.232

PACS: 68.35.Fx, 68.37.Hk, 81.15.Rs

\section{Introduction}

Thermal barrier coatings (TBCs) are widely used in hot section parts of gas turbine engines in order to protect structural materials from the hot gas streams and also increase thermal efficiency of system by reducing amount of cooling air or by increasing turbine inlet temperature. TBC systems are typically composed of thermal insulative ceramic topcoat and oxidation resistant $\mathrm{MCrAlY}$ bond coat deposited on substrate material. Bond coat layer is not only preventing the oxidation of substrate but it also provides thermal matching between topcoat and substrate material. TBCs are usually produced with atmospheric plasma spray (APS) or electron beam physical vapor deposition (EB-PVD) techniques. However, the plasma spray technique is largely used since it provides flexibility in system parameters and cost effectiveness [1-3]. Plasma sprayed TBCs contain much porosity, oxides and some horizontal or vertical microcracks lying at splat boundaries because of the nature of production process. This unique microstructure of coating is more expedient than EB-PVD counterparts in the way of low thermal conductivity. Thus, it is possible to produce

*corresponding author; e-mail: karaoglanli@bartin.edu.tr thinner coating, providing bigger temperature reduction or working higher temperatures $[4,5]$. In APS TBCs, thermally grown oxide (TGO) growth behavior and sintering of topcoat are most significant failure mechanisms to be examined.

TGO layer formed at topcoat/bond coat interface with the oxidation of bond at high temperature. Uniform, dense and low growing TGO layer is the most desirable oxide layer for oxidation resistance. This layer improves the service life of system by acting as a diffusion barrier. However, excessive growing of TGO layer or occurrence of other detrimental oxides and spinels such as $(\mathrm{Ni}, \mathrm{Co})(\mathrm{Cr}, \mathrm{Al})_{2} \mathrm{O}_{4}$ increase the internal stresses and eventually lead to spallation failure [6-8].

Sintering of ceramic topcoat is another damaging mechanism in TBCs as a result of exposure to high temperature atmosphere. Porous structure of ceramic layer undergoes some microstructural changes with sintering. Consequently, the coating becomes denser and brittle state healing of microcracks and reducing of porosity rate. After the cooling period, stress values in coating increase and ceramic layer comes over the delamination with the propagation of microcracks [9-11].

In this study, thermal barrier coating system consisting of YSZ (YSZ; $\mathrm{ZrO}_{2}+\mathrm{Y}_{2} \mathrm{O}_{3}$ ) ceramic topcoat and NiCrAlY metallic bond coat were deposited with atmospheric plasma spray technique on Inconel 718 substrate. Specimens were exposed to isothermal oxidation atmo- 
sphere at different conditions. After the oxidation, TGO layer formation and growth behavior were investigated. Additionally, durability of TBC system was evaluated by examining effect on mechanical properties of microstructural transformation in ceramic topcoat.

\section{Experimental}

Ni based Inconel 718 superalloy substrate material was used as the substrate material. Substrate materials disc shaped $(25.4 \times 4 \mathrm{~mm})$ and their surfaces grit blasted with alumina particles. A commercial NiCrAlY bond coat powder with a particle size range $45-75 \mu \mathrm{m}$ (AMDRY 962, Sulzer Metco, USA) and YSZ topcoat powder with a particle size range 11-125 $\mu \mathrm{m}$ (Metco 204NS, Sulzer Metco, USA) were used in spraying process. Both feedstock materials deposited with atmospheric plasma spray technique in Sulzer Metco Multicoat system, which has gas stabilized F4MB plasma gun. Spraying parameters and thicknesses of coating layers are stated in Table I.

\section{TABLE I}

Spraying parameters for NiCrAlY bond coat and YSZ top coat.

\begin{tabular}{c|c|c}
\hline \hline Parameter & NiCrAlY & YSZ \\
\hline current [A] & 600 & 630 \\
argon flow rate [slpm] & 45 & 45 \\
hydrogen flow rate [slpm] & 12 & 10 \\
spray distance [cm] & 12 & 9 \\
powder feed rate [g/min] & 35 & 30 \\
carrier gas [slpm] & 2.6 & 2.0 \\
power [kW] & 40 & 40 \\
thickness $[\mu \mathrm{m}]$ & $100 \pm 20$ & $300 \pm 20$
\end{tabular}

Particle size distribution was analyzed with Microtrac S3500 particle size analyzer before the production of TBC. Average surface roughness values $\left(R_{\mathrm{a}}\right)$ were measured with Mitutoyo SJ-201P surface roughness tester. Isothermal oxidation tests were carried out in Protherm high temperature furnace at $900^{\circ} \mathrm{C}$ for 8,24 , and $50 \mathrm{~h}$ and afterwards awaited for cooling to room temperature. Powder particle morphology and microstructures of TBC were examined using scanning electron microscope (SEM, Zeiss EVO/MA10) before and after the oxidation tests. Porosity rates are determined with image analysis software (ImageJ). Microhardness tests are completed with Shimadzu HMV-2 microhardness tester using Vickers indenter at a loading of $100 \mathrm{~g}$ for $15 \mathrm{~s}$.

\section{Results and discussion}

Nominal particle size $\left(D_{50}\right)$ of powders and average surface roughness $\left(R_{\mathrm{a}}\right)$ values are given in Table II. Surface roughness values are consistent with particle size according to the splash mechanism.

The cross-section SEM microstructures for produced $\mathrm{TBC}$ before and after oxidation tests are seen in Fig. 1.
TABLE II

Nominal particle size and average surface roughness.

\begin{tabular}{c|c|c}
\hline \hline Powders & $\begin{array}{c}\text { Nominal particle } \\
\text { size }[\mu \mathrm{m}]\end{array}$ & $\begin{array}{c}\text { Average surface } \\
\text { roughness }[\mu \mathrm{m}]\end{array}$ \\
\hline NiCrAlY & 75.22 & 13.16 \\
YSZ & 47.85 & 6.56
\end{tabular}

While the bond coat/topcoat interface is not evident as-sprayed state, TGO layer occurred as a result of oxygen penetration from ceramic top coating with the increasing oxidation time as seen in Fig. 1. The thickness of formed TGO structure showed an increase depending on oxidation time and this structure can also vividly be seen in microstructures in Fig. 1. $\mathrm{Al}_{2} \mathrm{O}_{3}$ layer formed in the interface of bond coat/topcoat as due to increase in oxygen and aluminium concentration. Some discontinuities closed and porosities decreased with the sintering effect after $50 \mathrm{~h}$ oxidation at $900^{\circ} \mathrm{C}$. The TGO thickness measurements were given as a function of the oxidation time in Fig. 2. The microhardness values and porosity measurements of the topcoats were given as a function of the oxidation time at $900^{\circ} \mathrm{C}$ for 8,24 , and $50 \mathrm{~h}$ in Fig. 3.

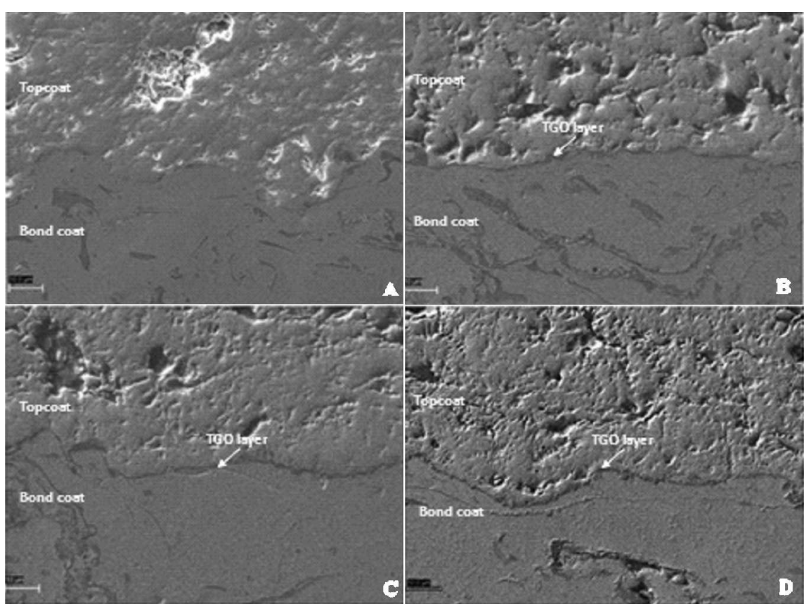

Fig. 1. Cross-sectional micrographs of the TBC systems: (a) as-coated TBC, (b)-(d) after oxidation at $900{ }^{\circ} \mathrm{C}$ for 8,24 , and $50 \mathrm{~h}$, respectively.

Average TGO thickness values of TBC systems are given in Fig. 2 for 8, 24, and $50 \mathrm{~h}$. All the TGO thickness measurements were carried out from the regions where TGO layer is continuous. As can be seen in Fig. 2, TGO growth at short-term oxidation is much lower compared to longer time oxidation tests at $900^{\circ} \mathrm{C}$.

In the TBC systems subjected to high temperatures, the porosity values of the topcoat decreased due to sintering effect. On the other hand, by means of the sintering effect, microhardness values of topcoat slightly increased depending on oxidation time and temperature as seen in Fig. 3. These microstructural and mechanical changes are more distinctive, especially after $50 \mathrm{~h}$ oxidation. 


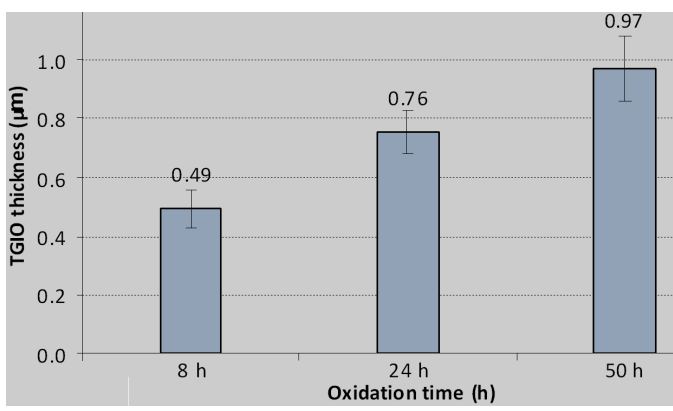

Fig. 2. TGO thickness measurements as a function of oxidation time at $900{ }^{\circ} \mathrm{C}$ for 8,24 , and $50 \mathrm{~h}$, respectively.

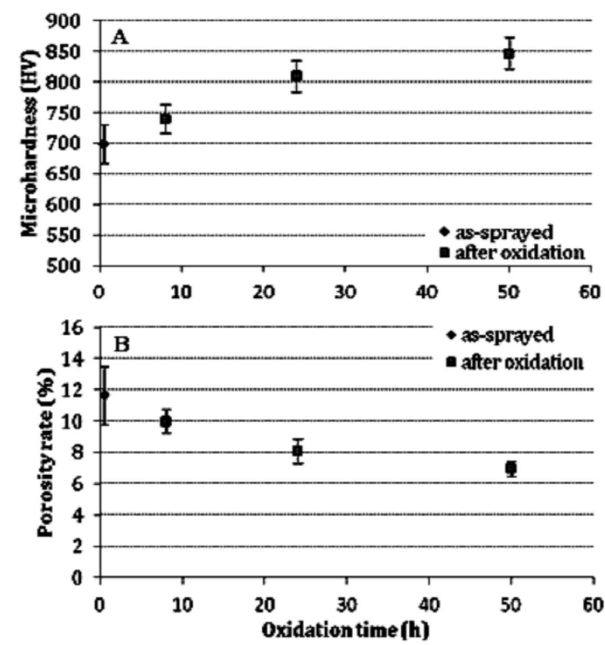

Fig. 3. (a) Microhardness and (b) porosity measurements as a function of oxidation time at $900{ }^{\circ} \mathrm{C}$ for 8 , 24 , and $50 \mathrm{~h}$.

\section{Conclusions}

In this study, NiCrAlY bond coat and YSZ topcoat were deposited with APS technique on Inconel $718 \mathrm{su}$ peralloy substrate. After the high temperature oxidation tests, which are applied depending on temperature and time parameters, the TGO growth behaviour was in- vestigated. Besides, hardness values and porosity rates of TBC system were measured. The TGO layer that is formed in the interface of bond coat/topcoat grew up depending on increasing oxidation times. As a result of sintering effect, porosity rates of ceramic topcoat decreased with the microstructural changes and densification of topcoat. This microstructural transformation caused the increase in hardness values of top coat. Consequently, TBC system became more prone to spallation failure after oxidation.

\section{Acknowledgments}

The authors would like to thank Prof. F. Ustel and his group members for thermal spray experiments (Sakarya University, Thermal Spray Research Center, Turkey).

\section{References}

[1] N.P. Padture, M. Gell, E.H. Jordan, Science's Compass 296, 280 (2002).

[2] M. Gell, E. Jordan, K. Vaidyanathan, K. McCarron, B. Barber, Y. Sohn, V. Tolpygo, Surf. Coat. Technol. 120-121, 53 (1999).

[3] K.A. Khor, Y.W. Gu, Thin Solid Films 372, 104 (2000).

[4] S.N. Basu, G. Ye, M. Gevelber, D. Wroblewski, Refract. Met. Hard Mater. 23, 335 (2005).

[5] W. Beele, G. Marijnissen, A. van Lieshout, Surf. Coat. Technol. 120-121, 61 (1999).

[6] A.C. Karaoglanli, E. Altuncu, I. Ozdemir, A. Turk, F. Ustel, Surf. Coat. Technol. 205, 369 (2011).

[7] W.R. Chen, X. Wu, B.R. Marple, D.R. Nagy, P.C. Patnaik, Surf. Coat. Technol. 202, 2677 (2008).

[8] A. Rabiei, A.G. Evans, Acta Materialia 48, 3963 (2000).

[9] K. Takagi, D. Kudo, A. Kawasaki, Y. Harada, Surf. Coat. Technol. 205, 4411 (2011).

[10] S. Paul, A. Cipitria, S.A. Tsipas, T.W. Clyne, Surf. Coat. Technol. 203, 1069 (2009).

[11] R.A. Miller, D. Zhu, Surf. Coat. Technol. 108-109, 114 (1998). 